\title{
Collaboration Model for Green Belt Management Area in Tegal City
}

\author{
Indra Kertati \\ \{kertati@yahoo.com\} \\ Universitas 17 Agustus 1945 Semarang, Indonesia
}

\begin{abstract}
This paper aims to evaluate the social collaboration model in managing green belts in Tegal City. The beach has been assessed. Abrasion struck almost the entire north coast of Central Java. Climate change has occurred, but not yet aware of the danger of environmental damage. Central Java Province has a northern coastline of 645 kilometers. The condition of the coast from Brebes to Rembang has been damaged. Abrasion has destroyed much of the area and has had a negative impact on the local government and community. The area of the beach green belt as a protective abrasion is only $20 \%$. Tegal City has long experienced abrasion to eliminate hundreds of hectares of fishponds, houses and community buildings and dense mangrove forests on the beach. In 2000, the initiation began to address the problem of coastal damage Collaborative models are used to overcome these problems. The method used is descriptive qualitative. The results showed collaboration success depends on stakeholder strength. Community participation functions if they are aware of the problem and have the intention to change the situation.
\end{abstract}

Keywords: Abrasion, Mangrove, Collaboration, Community.

\section{Introduction}

Abrasion has affected most of the northern coast of Central Java. There are twenty-three abrasion-prone points identified in Central Java which are spread across Brebes, Demak, Rembang, Jepara, parts of Pekalongan, Kendal and Tegal, and Semarang City. The abrasion incident was recorded as having eliminated the Semarang City coastal area of $154.5 \mathrm{Ha}$; the coast of Demak Regency $746 \mathrm{Ha}$, the coast of Kendal Regency $357.87 \mathrm{Ha}$; the coast of Pekalongan Regency 86.31 Ha; the coast of Batang Regency 36.08 Ha; and Pekalongan City covering an area of $47.15 \mathrm{Ha}$ [1]. In fact, Tegal City has at least 300 hectares of shrimp ponds and dozens of houses have been lost. The shore lost by the waves reached more than 100 meters, with a length of three kilometers [2].

Abrasion makes mangrove that grows along the coast of Tegal city is damaged. Mangroves only grow on ponds, and a small part in rivers. Damage to the mangrove cluster has damaged the green belt as a buffer to the community's ponds, and has reduced the productivity of the people's ponds.

Green belt is a formation of specific plants, and is generally found growing and developing in coastal areas that are protected in the tropics and subtropics [3]. Mangrove ecosystems cannot grow and breed well in various types of coastal typologies. A good 
mangrove ecosystem usually develops and forms in locations protected from ocean waves. Sediments from rivers and seas will be deposited and form tidal flats. The Java Sea is a relatively calm wave current with shallow depths, which supports the development of mangrove ecosystems [4][5].

The loss of the green belt area has encouraged the initiation of the government by launching a program of assistance from the Asian Development Bank, the Coastal Community Development and Fisheries Resources Management Project (COFISH) in 2000. The project is working with many elements such as local governments, communities, universities and NGOs to solving community problems. One of the interesting things is that the community initiated by the NGO LPPSP Semarang is to encourage community empowerment to manage the beach, especially the green belt. This activity is to increase public awareness of environmental management and restore mangroves as green belts [2].

Mangroves cannot grow as fast as other plants. The treatment is to make plots along the coast so that mangroves can grow quickly and be able to fortify plots with bamboo. This technique is carried out simultaneously by increasing the capacity of the community in managing the green belt area.

It's not easy to do this initiation. The situation at that time was very bad, such as a low level of community education, poverty in coastal communities, community organizations that have not yet been formed, and abrasion which at any time destroys mangroves. Almost frustrating, but the determination of the community with LPPSP has produced amazing results. This paper aims to evaluate the social collaboration model in managing green belts in Tegal City.

The evaluation method is carried out with a summative evaluation model Lehman [6] which compares the initial conditions through existing documents and the final conditions as a way to find out the benefits of a program.

\section{Methodology}

This research was conducted using qualitative methods. The qualitative approach specifically uses program impact evaluation. The indicators in this study are the level of benefits, community institutions and participation. Data collection methods used are in-depth interviews, document review, and observation.

This qualitative approach aims to explore ideas on the results and development of the green belt. Another approach is to do a historical search, documents and stories of the figures who have been involved. In the end triangulation is performed so that the results are compiled to answer the research objectives.

\section{Results and Discussion}

Evaluation is a systematic review of events that occur due to the implementation of a program (Harris, 1985). Evaluation is an activity aimed at measuring the success of a program [7]. Evaluation is the process of assessing how goals can be achieved. Thus, the evaluation calculates achievements from initial to final conditions. The aim is to find out the benefits of a project in the treatment period. 
Based on it is purpose, evaluation is distinguished in two ways: summative evaluation and formative evaluation. Summative evaluation is an effort to assess the benefits of a program and make decisions and formative evaluation is an effort to obtain feedback on program improvement [6]. Evaluation of the implementation of the green belt in the coastal area of Tegal city is carried out with a summative evaluation model that is to determine the impact of the program and make decisions in the form of research recommendations.

The community has benefited from the improvement of the green belt environment. This public awareness exists through a long process. The year 2000 began to be introduced to the public about the dangers of abrasion and climate change that could destroy their ponds. In 2001, the Green Belt construction began to be carried out with a puddle model.

A green belt is a physical separator of urban and rural areas in the form of a building free zone or green open space that surrounds the outside of an urban area or an activity center that causes pollution [8]. The Guidelines for Provision and Utilization of Green Open Space in Urban Areas (2008) state that a green belt is a green open space that functions as a buffer zone and to limit the development of a land use (city boundaries, zoning, etc.) or to limit one activity to another. not interfere with each other, as well as safeguards from surrounding environmental factors.

Green belt is the main element in the form of vegetation which naturally functions as an atmospheric cleaner by absorbing pollutants in the form of gases and particles through the leaves. Vegetation functions as a living filter to reduce pollution levels by absorbing, detoxifying, accumulating and regulating metabolism in the air so that air quality can be improved by releasing oxygen in the air [9].

The puddle model is applied in the form of a ten meter and three-meter hole with a depth of one meter. Each wall is surrounded with woven bamboo to hold back the sand that sometimes closes the puddle. That is where mangroves are planted with a distance of fifty centimeters with seedlings as high as sixty centimeters.

This model was initiated by the NGO Development Resources Development and Assessment Agency (LPPSP) with stakeholders. This model was developed because planting mangroves on the beach is easily damaged due to abrasion prone and covered with sand. The application of this model is not always smooth. In addition to requiring large costs (one puddle costs nine hundred thousand rupiah), this model requires intensive care, especially pests, sand, and water needs at least one day a week must contain water.

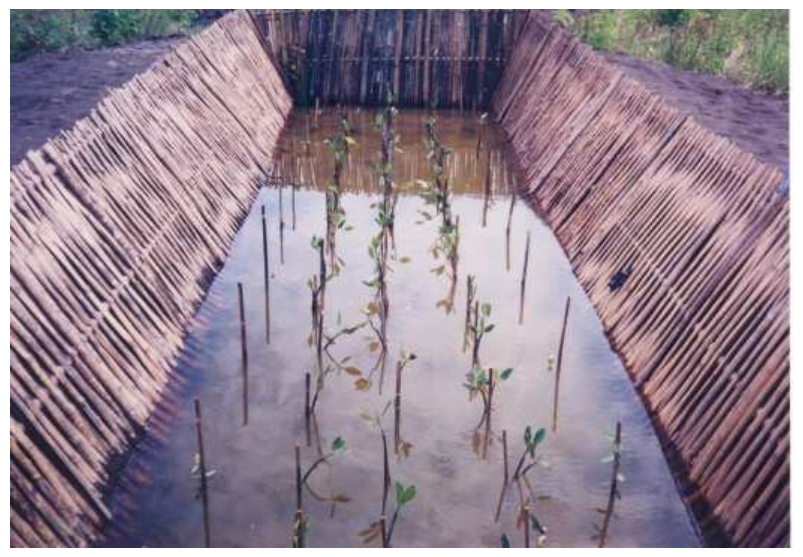

Fig. 1. Puddle Model. 
This model was implemented with a Coastal Community Development and Fisheries Resource Management Project (COFISH) grant for five years and was continued by UNDP and LPPSP for two years. Now this benefit has been realized by the community. The area of mangrove as a $4.800 \mathrm{~m} 2$ green belt stretches from the coast of Panggung Village to Mintaragen. Some of the benefits obtained by the community are an increase in the community's economy. Since the COFISH Tegal project ended in 2007, and was handed over to the Tegal City government, the innovation was developed. Green Belt has become a new tourism area for the City of Tegal. Green Belt is not only as an abrasion barrier but as an oxygen-absorbing buffer and tourist destination.

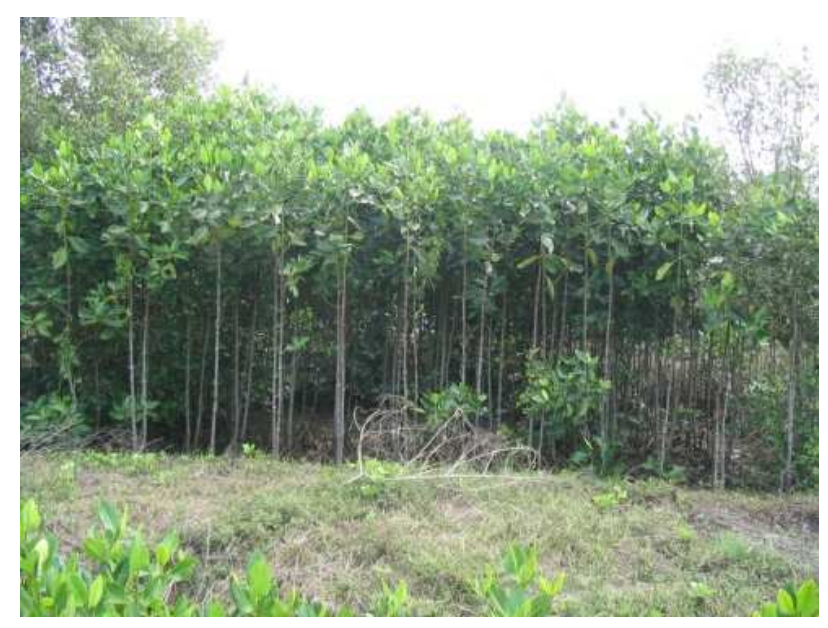

Fig. 2. Current condition of mangroves.

The results of the Tegal city mangrove mapping are as follows:

Table 1. Mapping of Tegal City Mangroves as Green Belts

\begin{tabular}{|l|c|c|c|c|c|}
\hline Village & $\begin{array}{c}\text { Long beach } \\
\text { (Km) }\end{array}$ & $\begin{array}{c}\text { Amount of } \\
\text { Puddle }\end{array}$ & $\begin{array}{c}\text { Number of } \\
\text { plants }\end{array}$ & $\begin{array}{c}\text { Number of } \\
\text { Damaged Plots }\end{array}$ & $\begin{array}{c}\text { Rest the } \\
\text { Puddle }\end{array}$ \\
\hline Muarareja & 2,31 & 156 & 23.840 & 107 & 49 \\
\hline Tegalsari & 0,62 & 20 & 3.200 & 0 & 20 \\
\hline Panggung & 1,75 & 132 & 21.120 & 30 & 102 \\
\hline Mintaragen & 0,32 & 102 & 16.320 & 8 & 94 \\
\hline Total & 5,00 & 410 & 65.600 & 145 & 265 \\
\hline
\end{tabular}

Source: DLH Mangrove Mapping Results 2016 Tegal City.

The results of the 2016 Tegal City Environment Department mapping program showed that there were 65,600 mangroves that had been planted in the five-kilometer long coast. Of these there are 265 maps left (DLH Report, 2018). Of this number currently managed by three groups namely the Prosperous Group in the Village Panggung, Wono Segoro in Mitaragen and Pantai Hijau in Muarareja.

Since 2009, green belts have not only been planted with mangroves but also sea fir. These seeds were donated from the Central Java Provincial Environment Agency and the Tegal City Environment Agency. From 2009 to 2018 there were 55,463 mangrove stems and 22,650 sea cypresses embedded. This number is not all live. At present there are 34,970 
mangroves. Some of the causes of the reduction in greenbelt due to seawater bottlenecks that supply water at the Mintaragen beach green belt site, mangrove clearing for the construction of tourism roads, opening new ponds by the community, and community awareness that is not yet optimal in greenbelt management.

Some of the initiatives developed are strengthening the economy through the use of mangrove forests as a tourism asset, the growth of modern aquaculture businesses, the impact of tourism can make new businesses a shop for the local community. In terms of institutionalization, the community has been facilitated to join the coast rescue organization. Community organizations have been formed since 2001, until now they still exist and are running. They are Sejahtera (Panggung), Wono Segoro (Mintaragen) and Pantai Hijau (Muarareja) groups. This organization survived until now, unfortunately the regeneration of this organization stagnated. Trust in a community leader who is considered successful does not encourage new figures to join the environment.

After the management of the Alam Indah Beach which contains a cluster of mangroves to the Office of Tourism, this group is side by side and even it is members are the same as the Tourism Awareness Group (POKDARWIS).

The tendency towards tourism causes these groups to concentrate less on developing greenbelt but more on providing tourism areas. The impact of attention to the green belt is less than optimal.

Economic factors become more dominant. Fighters must think about the economic viability of their members. The orientation to fulfill life needs is more prominent. Voluntaries who are expected to grow in managing green belts must deal with economic needs. Massive buildings on the beach for tourism, has turned off sea water sources for mangroves. Seawater flow to the green belt for mangrove life and development is interrupted. Finally, the green belt only relies on rain water.

Social factors found are that mangrove management community organizations do not get incentives in mangrove management. Only a small number of managements still survive in the current green belt condition, which is relying on the results of parking management. Previously, these groups received incentives from mangrove maintenance by COFISH Projet, Local Government and CSR. Currently Community Organizations, especially in Mintaragen, experience institutional stagnation.

Since the arrival of COFISH the level of stakeholder participation has increased. The success of mangrove planting has encouraged various parties to carry out similar activities that strengthen the green belt development. Stakeholder collaboration has proven the success of green belt development at least until 2015. The Provincial Government through the Office of the Environment, the Office of the Environment, the Office of Tourism, the Public Works Office of Tegal City, several banks such as BNI 46, BPD, Bank Mandiri, Pancasakti University, Tegal, and the community involved in developing green belts. The key to this success is stakeholder collaboration. 


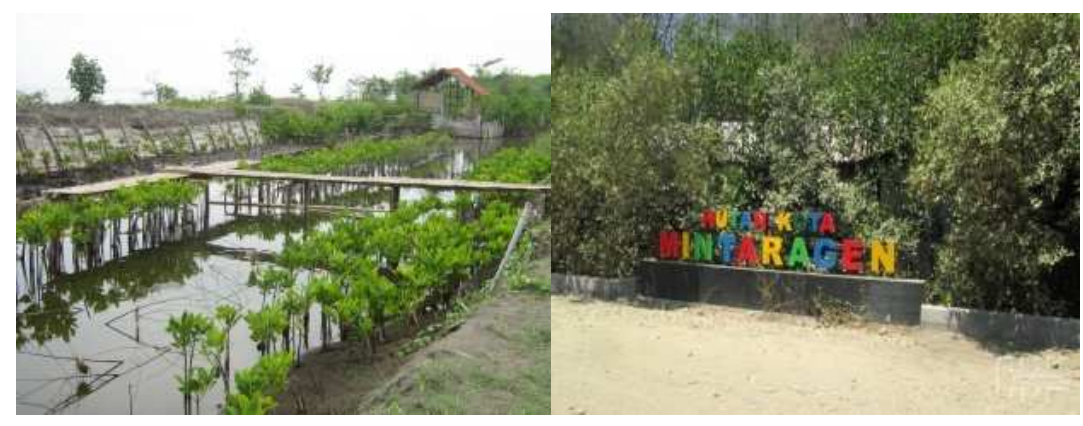

Fig. 3. Comparison of conditions at the time of initiation and current conditions that have become green belt areas

Collaboration in managing a green belt area is a framework that describes a situation of one or more social actors negotiating, defining and agreeing among themselves regarding the division of roles and responsibilities for managing a particular resource area and ensuring an equitable sharing of benefits over these resources [10]. Collaborative management is the process of developing cooperation between relevant parties, especially between local communities and natural resource users, who already have clear functions, rights and responsibilities. This collaborative approach is important because (1) conservation efforts require attention in linking the interests of biodiversity and culture that provide space for local and indigenous communities to be active and empowered during collaboration; (2) conservation requires attention in the principle of equality and fairness, both the distribution of costs and benefits received both in the protection of biodiversity, natural resource management and it is utilization; (3) conservation requires respect for the socio-economic rights of the people [11].

The terms of collaboration are equality and mutual reinforcement. The collaboration that has been formed has not been as strong as in previous years. Community orientation towards economic needs is increasingly prominent, while each Dinas has goals, visions and missions that must be realized.

Lai [12] explains that collaboration is joint involvement in coordinated efforts to solve problems together. Collaborative interaction is characterized by shared goals, a symmetrical structure with high-level negotiations through infertility and interdependence. Barbara Gray [13] observes that collaboration can only be meaningful if stakeholders are interdependent. Collaboration is giving and receiving among stakeholders to produce solutions that cannot be achieved by those who work independently. In this way, they all depend on each other to produce mutually beneficial solutions.

The concept referred to by Barbara Gray [13] about collaboration in the development of green belt areas occurs because each stakeholder is interdependent. A damaged green belt is an object to be managed by the government, local government, lCOFISH, UNDP, the community, NGOs, universities, and other stakeholders. Each stakeholder works according to their respective duties and functions.

As the project ended, and NGOs returned to their regions, the community together with the local government made innovations. Independent communities develop themselves towards increasing income. Local governments implement activity plans in accordance with their respective affairs. The approach changed to be more practical, without the process of raising citizen participation. This change in orientation results in a reduction in the power of 
collaboration. Stakeholders work in accordance with organizational goals and forget about existing networks.

There are three important lessons that can be learned from the management of the green belt in the city of Tegal by the local government. First, increasing the capacity of community organizations in managing the green belt must continue. The two regional governments must encourage the community to care about beach damage and the three elements of collaboration must be reorganized to fix the group, improve the quality of the environment and achieve the mission of improving environmental sustainability.

\section{Conclusion}

The results of this study concluded that:

a. The community has benefited from the medium- and long-term benefits of building a beach green belt. These benefits are the return of land that was destroyed by abrasion, increased income, beautiful green belts, formed community leaders who care about the environment and the existing stakeholder network. Unfortunately, the collaboration that was formed was not strong.

b. Institutionally, the organization formed in 2001 is still strong, but the management of the organization has not changed and has remained for 19 years. The weakness of this element is organizational stagnation, that is, the organization is managed by the old management, with slow regeneration. Members of the organization hold concurrent positions in other groups managed by the Department of Tourism. The impact of reducing the orientation of environmental protection and switch to tourism. The group is in a comfort zone that is underdeveloped.

c. Green belt management collaboration has been good, unfortunately the orientation of the vision has changed from the environment to the economy. NGO assistance is needed to facilitate the community, and strengthen collaboration in the sustainability of green belts.

\section{References}

[1] I. W. W. Y. Mahendra, E. Maulana, T. R. Wulan, A. Dwi, W. Rahmadana, and A. S. Putra, "Pemetaan Kawasan Rawan Abrasi di Provinsi Jawa Tengah Bagian Utara," ("Mapping Abrasion Prone Area Cent. Java Prov. Bunga Rampai, Kepesisiran dan Kemaritiman (Collection Artic. Coast. Marit., vol. 2, pp. 93-105, 2016.

[2] et al Gunarto, "Mapping the Potential and Problems of Tegal City Coastal Communities," Final Report, COFSH Tegal., 2000.

[3] Pramudji, "Mangrove Forest Ecosystem and It is Role as a Habitat for Various Aquatic Fauna, Oseana," vol. 26, no. 4, pp. 13-23.

[4] C. G. G. J. van. STeenis, Ecology of Mangroves. Flora Malesiana. Noordhoff-Kollf. Djakarta, 1958.

[5] C. G. G. J. van Steenis, "Concise plant-geography of Java. Flora of Java,” vol. 11, 1965.

[6] H. Lehmann, "The systems approach to education. special presentation conveyed in the international seminar on educational innovation and technology manila." Innotech Publications, 1990.

[7] S. Arikunto, West Java Evaluation of Educational Programs. Jakarta: Earth Literacy, 2004.

[8] A. Mustika., "Green Belt and It is Relationship with Quality of Life in Urban Communities," Environ. Biol. Pap. Environ. Sci. Study Program, Prog. Postgrad. Univ. Gadjah Mada, 2005. 
[9] and R. C. S. Shannigrahi, A S T. Fukushima, "Anticipated air pollution tolerance of some plant species considered for green belt development in and around an industrial/urban area in India," J. Environ. Stud.

[10] et al. Borrini-Feyerabend, G, "Co-Management of Natural Resources: Or- ganizing, Negotiating and Learning by Doing."

[11] Borrini-Feyerabend, "Quality and Vitality: to- wards Shared Language and more Secure and Lasting Prospects for the Conserva- tion of Nature," G.Governance Divers., 2015.

[12] E. R. Lai, Collaborations: A Literature Review. 2011.

[13] B. Gray, "Collaborating: Finding Common Ground for Multiparty Problems San Francisco: Jossey-Bass,” 1989. 